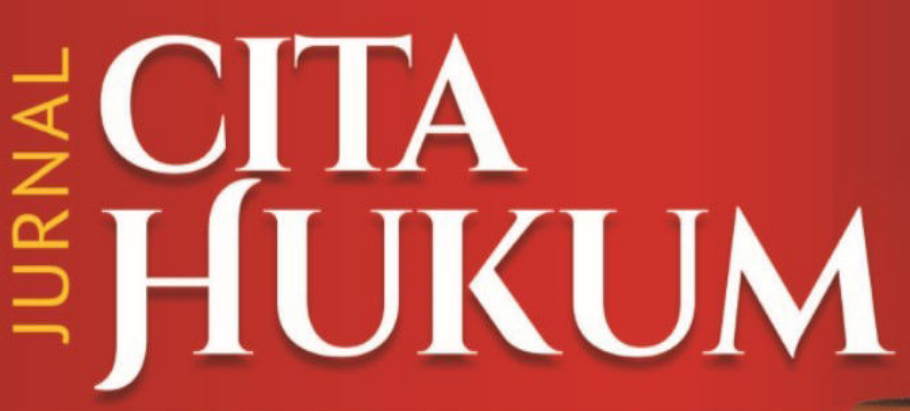

Indonesian Law Journal

- Related with Judicial Conditions in The Civil Case Evidence in The Court (Case Study of Decision No. 47 / Pdt.G / 2012 / PN Lsk and Decision No. 16/Pdt.G/2012/PN Stb)

Efa Laela Fakhriah \& Yustika Tatar Fauzi Harahap

- Model Setting of Political Party System and Electoral Systems to Prevent Political Corruption Agus Riwanto \& Achmad

- A Patient's Legal Protection as a Victim of Sexual Harassment on Medical Services in Indonesia

Siska Elvandari \& Mey Lin Chan

- Filling the Position of Constitutional Court Judge and Its Correlation with the Independence of Judges (Comparative Study of Some Countries)

M. Beni Kurniawan

- The Institutional Renewal in Settlement of Disputes of Local Election Results Heru Widodo

- The Rebellion Indication Towards Sovereign Government in Acts of Terrorism in Indonesia In Transcendental Dimension

Irfan Hielmy \& Nur Rohim Yunus

- Politik Hukum Dalam Kebijakan Hukum Pidana LGBT

Iqbal Kamalludin, Hirda Rahma, Aldila Arumita Sari \& Pujïyono

- Pengaruh Konvensi Hukum Laut Internasional Tahun 1982 Terhadap Wilayah Laut Indonesia Yoyon Mulyana Darusman

- Pengawasan Pengurus Ikatan Notaris Indonesia Kota Padang Terhadap Pelaku Pelanggaran Kode Etik

Nisaul Hasanah, Azmi Fendri \& Neneng Oktarina

Volume 6 Number 2 (2018) 


\section{Jurnal}

\section{CITA HUKUM}

\section{VOLUME 6 NUMBER 2 (2018)}

CITA HUKUM is Indonesian Law Journal published by Faculty of Sharia and Law, State Islamic University Syarif Hidayatullah Jakarta in Associate with Center for Study of Indonesian Constitution and Legislation (POSKO-LEGNAS) UIN Jakarta.

This journal specializes in Indonesian Legal Studies and try to present various results of the latest and high-quality scientific research which is issued twice in a year at June and December.

CITA HUKUM has been indexed at DOAJ, EBSCO, Microsoft Academic Search, Emerging Source Citation Index (ESCI) Clarivate Analytics, and SINTA 3 and become a CrossRef Member since year 2015.

Therefore, all articles published by CITA HUKUM will have unique DOI number.

\section{INTERNATIONAL ADVISORY BOARD}

Prof. Tim Lindsey, SCOPUS ID: 36785442900; h-index: 5, Melbourne University Australia

Prof. Muhammad Munir, Scopus ID: $54414595100 \mathrm{~h}$-index: 1, Department of Law, International Islamic University Islamabad, Pakistan Prof Mark Cammack, Scopus ID: $6507998992 \mathrm{~h}$-index: 3, Southwestern Law School Los Angeles USA

Prof. Euis Nurlaelawati, Scopus ID: 56247081700 h-index: 1, Faculty of Sharia and Law, UIN Sunan Kalijaga Yogyakarta

\section{EDITORIAL BOARD}

Prof. Gani Abdullah, h-index Google Scholar: 5, UIN Syarif Hidayatullah Jakarta

Prof. Salman Maggalatung, h-index Google Scholar: 3, UIN Syarif Hidayatullah Jakarta

Dr. Asep Saepudin Jahar, Scopus ID: 57156653300, h-Index Google Scholar: 1, UIN Syarif Hidayatullah Jakarta

Dr. Ahmad Tholabi Kharlie, Thomson Reuters Id: R-5028-2017, h-Index Google Scholar: 3, UIN Syarif Hidayatullah Jakarta

\section{EDITOR IN CHIEF}

Nur Rohim Yunus, Thomson Reuters Researcher ID: F-3477-2017, ORCID ID: 0000-0003-27821266, SSRN ID: 2645355, h-index Google Scholar: 4, Department of Constitutional Law, UIN Syarif Hidayatullah Jakarta, Indonesia

\section{MANAGING EDITOR}

Muhammad Ishar Helmi, Thomson Reuters Researcher ID: F-3345-2017, ORCID ID: 0000-0001-7060-8191, h-index Google Scholar: 2, Department of Criminal Law UIN Syarif Hidayatullah Jakarta, Indonesia

\section{EDITORS}

Indra Rahmatullah, ORCID ID: 0000-0002-6160-4225, h-index Google Scholar: 2, Department of Economic Law, Faculty of Sharia and Law, UIN Syarif Hidayatullah Jakarta, Indonesia.

Mara Sutan Rambe, ORCID ID: 0000-0001-5404-6635, h-index Google Scholar: 1, Department Criminal Law, Faculty of Law, UIN Syarif Hidayatullah Jakarta, Indonesia.

\section{ENGLISH LANGUAGE EDITOR}

Fitria, ORCID ID: 0000-0001-9733-1233, Department of International Law, York Law School, University of York, UK, United Kingdom.

\section{ASSISTANT TO THE EDITORS}

Erwin Hikmatiar, Thomson Reuters Researcher ID: F-3235-2017, ORCID ID: 0000-0003-4103-818X, UIN Syarif Hidayatullah Jakarta

\section{Redaktur Office}

Faculty of Sharia and Law UIN Syarif Hidayatullah Jakarta

Street Ir. H. Juanda 95 Ciputat Jakarta 15412

Phone. (62-21) 74711537, Faks. (62-21) 7491821

Website: www.fsh-uinjkt.net, E-mail: jurnal.citahukum@uinjkt.ac.id

Link: http://journal.uinjkt.ac.id/index.php/citahukum 


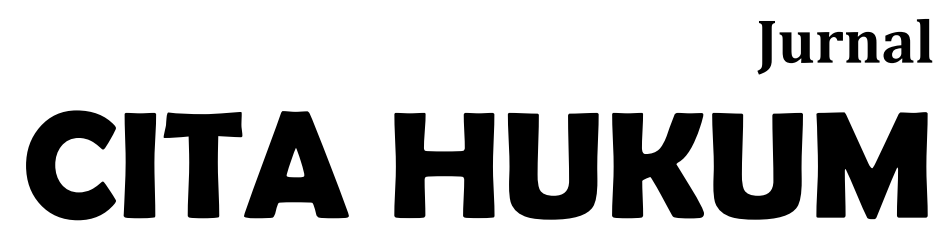

INDONESIAN LAW JOURNAL

Welcoming contributions from scientists, scholars, professionals, and researchers in the legal disciplines to be published and disseminated after going through script selection mechanisms, reviewing sustainable partners, and rigorous editing processes. 


\section{TABLE OF CONTENTS}

Related with Judicial Conditions in The Civil Case Evidence in The Court (Case Study of Decision No. 47 / Pdt.G / 2012 / PN Lsk and Decision No. 16/Pdt.G/2012/PN Stb)

Efa Laela Fakhriah, Yustika Tatar Fauzi Harahap 201-216

Model Setting of Political Party System and Electoral Systems to Prevent Political Corruption

Agus Riwanto, Achmad $217-234$

A Patient's Legal Protection as a Victim of Sexual Harassment on Medical Services in Indonesia

Siska Elvandari, Mey Lin Chan.

$235-252$

Filling the Position of Constitutional Court Judge and Its Correlation with the Independence of Judges (Comparative Study of Some Countries)

M. Beni Kurniawan. 253-276

The Institutional Renewal in Settlement of Disputes of Local Election Results Heru Widodo 277-292

The Rebellion Indication Towards Sovereign Government in Acts of Terrorism in Indonesia In Transcendental Dimension

Irfan Hielmy, Nur Rohim Yunus 293-316

Politik Hukum Dalam Kebijakan Hukum Pidana LGBT (Legal Politics in the LGBT Criminal Law Policy)

Iqbal Kamalludin, Hirda Rahma, Aldila Arumita Sari, Pujiyono $317-342$

Pengaruh Konvensi Hukum Laut Internasional Tahun 1982 Terhadap Wilayah Laut Indonesia (The Influence of the 1982 International Convention on the Law of the Sea against the Indonesian Ocean Territory)

Yoyon Mulyana Darusman $343-360$

Pengawasan Pengurus Ikatan Notaris Indonesia Kota Padang Terhadap Pelaku Pelanggaran Kode Etik (Supervision of the Management of the Indonesian Notary Association in Padang City Against Perpetrators of the Code of Ethics)

Nisaul Hasanah, Azmi Fendri, Neneng Oktarina 361-386 



\title{
The Institutional Renewal in Settlement of Disputes of Local Election Results*
}

\author{
Heru Widodo ${ }^{1}$ \\ Legal Consultancy and Assistance Institutions (LKBH), Padang
}

DOI: $10.15408 /$ jch.v6i2.8690

\begin{abstract}
.
Since the first step of local election in 2015, the authority of adjudicating a dispute of local election's result has been run by The Constitutional Court until a special judicial board before the national election held. An ideal design of the institutional renewal to adjudicate a controversy of local election's result, could be a part of judicial environment under The Supreme Court supervision, or may becomes a new institution or replaces another institution by attaching to the authorized institution, named: Bawaslu, PT TUN or Constitutional Court. Bawaslu was become the one of the institutions which fulfills the requirements. Started from a legislative election on 2014, Bawaslu has an authority of resolving a dispute among the candidates of general election or between the candidates and the committee. Since the national election in the year 2017, Bawaslu has given the authorization to settle up an administrative violation, a conflict of local election and to handle a money politics through TSM. The authority of the dispute court of election results is proposed not only on the controversy over the calculation result, but also including unreachable legal phenomenon with law enforcement on criminal system and stage of election dispute, as an inseparable part.
\end{abstract}

Keywords: Institutional Renewal, Dispute Result, National Election

\footnotetext{
*Received: July 26, 2018, revised: August 11, 2018, Accepted: November 20, 2018.

${ }^{1}$ Heru Widodo is a researcher and lawyer at Legal Consultancy and Assistance Institutions (LKBH), Padang, West Sumatra, Indonesia. E-mail: heru.widodo@gmail.com.
} 


\title{
Heru Widodo
}

\section{Pembaharuan Kelembagaan Dalam Penyelesaian Sengketa Hasil Pemilukada Serentak}

\begin{abstract}
Abstrak.
Sejak pemilihan serentak tahap pertama tahun 2015, wewenang mengadili sengketa hasil pemilukada dijalankan Mahkamah Konstitusi sampai dibentuk badan peradilan khusus sebelum pelaksanaan pemilihan serentak nasional. Disain pembaharuan kelembagaan yang ideal untuk mengadili sengketa hasil pemilukada serentak, dapat menjadi bagian dari lingkungan peradilan di bawah Mahkamah Agung, dapat pula menjadi lembaga baru ataupun mereposisi lembaga dengan cara melekatkan pada lembaga yang saat ini berwenang menyelesaikan sengketa pemilihan, yakni: Bawaslu, PT TUN atau MK. Bawaslu menjadi salah satu pilihan lembaga yang memenuhi persyaratan. Sejak Pemilu Legislatif 2014, Bawaslu berwenang menyelesaikan sengketa antarpeserta pemilu maupun antara peserta dengan penyelenggara, dan sejak Pemilukada Serentak 2017, bahkan diberi wewenang memutuskan pelanggaran administrasi, sengketa pemilukada sampai penanganan politik uang (money politics) secara TSM. Kewenangan peradilan sengketa hasil pemilihan diusulkan tidak hanya atas perselisihan atas hasil perhitungan, tetapi memasukkan peristiwa hukum yang tidak terjangkau dengan penegakan hukum dalam sistem pidana dan tahap sengketa pemilihan, sebagai bagian yang tidak terpisahkan.
\end{abstract}

Kata kunci : pembaharuan kelembagaan, sengketa hasil, pemilukada serentak

Recommended Citation:

Widodo, Heru. "The Institutional Renewal in Settlement of Disputes of Local Election Results" JURNAL CITA HUKUM [Online], Volume 6 Number 2 (2018). 


\section{Introduction}

The dynamics of resolving a controversy over local election's result since the first time of head and deputy regional head was held in 2005 has a significant development. While applying a positive law, new things are appeared as a "best practice" giving an inspiration for renewal in the future.

A study of institution renewal which given an authorization for solving a controversy of election result, which is currently held simultaneously, cannot be separated from the three things first, a practice which held in the past; second, a practice which is currently occurs; and, third, the idea in the future.

In practice which held in past, there are two institution given by an authority to resolve a dispute of election result, both are The Supreme Court (MA), and then being diverted to the Constitutional Court. The existence of Constitutional Court, was being corresponded on Article 24C section (1) and (2) of the constitution of Republic of Indonesia in year 1945 concerning an authority of Constitutional Court by expresses verbis and a limitative cannot be interpretating or adding, except by the regulation in the same degree. Moreover, the authority of Constitutional Court which has been regulated in the Indonesia constitution 1945 is constitutionally. According to the interpretation study or a constitution study, an addition of authority, as Bagir Manan said, must be regulated on Indonesia Constitution, not by the legal law. ${ }^{2}$

Similarly, according to Constitutional Court decision number 97/PUU$\mathrm{XI} / 2013$, it's clearly stated that on the article 236C of the Law number 12 in the year 2008 and article 29 section (1) letter e of the Law number 48 in 2009 which regulated on giving the other authority by Constitutional Court was contradicted to the Indonesia Constitution 1945. Therefore, the authority of resolving a dispute of election's result cannot be taken by Constitutional Court in the future, except the authority was given by a changing (the fifth) of Indonesia Constitution 1945.

Today's reality, the local election which held concurrently, the law was regulated an authority of adjusting the dispute of election result to the special judicial board which can be formed before the national election. The controversy of the determination of final stage vote as the election result will be

\footnotetext{
2 Bagir Manan, this opinion is being delivered in the welcome speech in book publishing by the title "A Monumental decision, Answer the problematic state" written by Jimly Asshiddiqie and friends, associating Setara Press and The Jurisprudence Review Forum: Malang, 2016.
} 


\section{Heru Widodo}

checked and judged by Constitutional Court as far as the special justice board formed. ${ }^{3}$

Since the first step on general election held in 2015, the authority to judge a result of general election was tentatively and transitionally run by Constitutional Court. Those authority was obtained as far as the special judicial board formed, by limit of time before the national election held. The law does not regulate further relating to the formation of special judicial board which told before. Due to an absence of further regulation, then the interesting subject to be discussed is how a renewal design of an ideal institution to judge a controversy of national election's result.

\section{The Basis of Constutionality and The Alternative Choice of Institutional Design}

A Controversy, build upon Hans Kelsen, is happened because of the one hand was filed a claim to the other hand. ${ }^{4}$ Dean G. Pruitt and Jeffrey Z. Rubin ${ }^{5}$ giving a meaning of controversy as a perceived divergence of interest, or a belief that the aspiration of the disputants has not been reached simultaneously due to the differences of interest. Richard L. Abel, ${ }^{6}$ bear a meaning for a dispute as a public statement of inconsistent claim towards a valuable thing or because of an incompability aspect for the one side through something which has value.

In case of local election, a dispute or a controversy is basically happen on public. ${ }^{7} \mathrm{~A}$ dispute of local election can be interpreting as a contradiction of the election result. A controversy of general and local election, is consist of either political question or legal question, over legal context as a final decision on resolving a conflict. The Issue of local election faced a deadlock politically then resolved legally. Some experts stated that either national or local election

3 The Law number 10 in year 2016 concerning on $2^{\text {nd }}$ changing of the law number 1 in 2015 about the establishment of government law as a change of the law number 1 in 2014 on the governor election, bupati and mayor to the Law on article 157.

${ }^{4}$ Hans Kelsen, Pengantar Teori Hukum, Nusa Media: Bandung, 2012, p.130

5 Salim HS dan Erlies Septiana Nurbani, Penerapan Teori Hukum pada Penelitian Tesis dan Disertasi, Jakarta: Raja Grafindo, 2013, p.136.

${ }^{6}$ Lawrence M. Friedman, Sistem Hukum Perspektif Ilmu Sosial, (A Legal System a Social Science Perspective), diterjemahkan oleh M. Khozim, Bandung: Nusa Media, 2009, p.11. See also: Nur Rohim Yunus, Restorasi Budaya Hukum Masyarakat Indonesia, Bogor: Jurisprudence Press, 2012, p.66.

${ }^{7}$ A public interest on general or local election is related to the fundamental rights which has been widely recognized, is right to participate in government honestly and fairly. 
conflict as non-justiciable which cannot be questioned juridically. Those problem contains political questions. As the perspective of Jusice Brennan, a dispute categorized as non-justiciable or containing political questions, if "a lack on judicially discoverable and manageable standards for resolving it." ${ }^{8}$

There is various model of resolving a conflict of national and local election over the world. A model of resolving a dispute of election which applied in a country determines a legitimacy of the election itself. A good model can be one of the bases on constructing a stable political system and the legal system. ${ }^{9}$

As the statement of Jesús Orozco Henriquez, the model can be divided into five models those are: a) Political Bodies, Assemblies, or Representative Electoral Colleges; b) Nonspecialized Judges, usually under Supreme Court Jurisdiction; c) Constitutional Courts; d) Electoral Courts; e) Ad Hoc or Provisional Bodies. ${ }^{10}$ Indonesia has made a choice to resolve a dispute of election through the judiciary. In context of simultaneous local election, the law maker has determined in the formation of special judicial board.

There are many possibilities designs in the formation of special judicial board, by it character could be permanently or ad hoc. According to the existence can be formed into part of judicial environment under the supervision of Supreme Court, as a new board, or can be replaced a board in organizing a local election which has been existed before. The constitutional basis to create a special judicial board as a part of judicial environment under the supervision of MA is written on the article 24 section (2) of the Indonesia Constitution 1945, which reads:

A judicial control is taken by The Supreme Court (MA) and judicial board under his supervision in the general court environment, religious court, military court, state administrative court environment, and by the Constitutional Court (MK).

${ }^{8}$ Aharon Barak, The Judge in a Democracy, New Jersey: Princeton University Press, p.179.

${ }^{9}$ Legal Framework of Electoral Disputes Resolution, The encyclopedia of The Electoral Knowlage Network, dalam Susi Dwi Harijanti dan Ali Abdurrahman, "Model Penyelesaian Sengketa Pemilu Oleh Mahkamah Konstitusi: Studi Perbandingan Antara Indonesia Dan Jerman", Laporan Penelitian Fakultas Hukum Universitas Padjadjaran, Bandung 2011.

${ }^{10}$ Jesús Orozco Henriquez, The Mexican System of Electoral Conflict Resolution in Comparative Perspective, Taiwan Journal of Democracy, Volume 2, No.1, h. 51-60, dalam Susi Dwi Harijanti dan Ali Abdurrahman, Loc. Cit. 
In such case, the institution called as "a special court", which can only be formed in one of the judicial coverage under the Supreme Court. Judicial coverage under the Supreme Court are consist of General Court, Religious Courts, Military Court, or Administrative Court. Among the four courts, The Special District Election Court, can be placed under general court or administrative court. As an open legal policy, choice of establishing a special court can be placed under General Court or Administrative Court.

As for the constitutional basis to form a special judicial board as a new institution to replace an exist board, based on article 24 section (3) of Constitution of Republic of Indonesia 1945, which has determined that: "The other boards which purposed related to judicial authority has been regulated on the constitution. Those boards are situated outside the Supreme Court, yet still have a function which related to the judicial power.

Thirdly, the institutional idea in the future. As political question, a dispute of local election result should ideally solve by the election organizer institution itself without involving the judiciary. There is a suggestion for the establishment of a special judicial board by repositioning Organizer Honor Council (DKPP) or Election Supervisory Bodies (Bawaslu), so The Supreme Court and the other court under it will not be involved.

Several things that can be proposed in the institutional reform of the dispute resolution of the election result of regional heads: First, reformation without forming a new institution, but it is sufficient to attached the authority to settle a dispute over the result to an existing election dispute settlement institution. Second, description of the law enforcement mechanism for offenses and electoral disputes, start from the pre-registration phase, campaign phase, election phase to election dispute settlement are regulated in simultaneous election law (Law Number 1 year 2015 juncto Law Number 8 Year 2015 juncto Law Number 10 Year 2016). Towards offense of the code of ethics of the election organizer, settlement authority is granted to DKPP. ${ }^{11}$ While administrative offense, are granted to KPU. ${ }^{12}$ Disputes between electoral participants and disputes between participants and election organizer, are granted to provincial

${ }^{11}$ Law Number 1 Year 2015 About The Stipultation of Government Regulation of Law Number 1 Year 2014 on The Election of Governors, Regents and Mayors became the law, as amended the second time by Law Number 10 Year 2016, Article 136-137.

${ }^{12}$ Law Number 1 Year 2015 About Establishment of Government Regulation in lieu of Law Number 1 Year 2014 Article 138-141 
Bawaslu and/or Panwaslukada. ${ }^{13}$ Criminal Offense of the election, settlement authority is on District Court or High Court. ${ }^{14}$ Towards state administrative dispute, settlement authority is on Adminstrative High Court and Supreme Court. ${ }^{15}$ As for election disputes, settlement authority is on special judicial body, transitional in the Constitutional Court. ${ }^{16}$

From the description below, there are three institution currently authorized to resolve election disputes, i.e: Bawaslu, Administrative High Court, and Constitutional Court (transitional). It shows that conseptually, either Bawaslu or Administrative High Court, both have the authority for election disputes. But, administrative high court for administrative disputes and Bawaslu for interpersonal disputes and dispute between participants and the organizers as well as for money politics offense that are TSM, as regulated in Article 73 Law Number 10 Year 2016. Therefore, there are alternative institutional options that can be authorized to adjudicate disputes over the election results of the three institutions currently authorized to resolve election disputes: Bawaslu, Peratun or Constitutional Court. The choice to the Constitutional Court is no longer an alternative to the proposal as long as the additional authority to examine and adjudicate the dispute over the results of the regional head is not added with the same degree, namely with the amendment of the Indonesia Constitution 1945.

According to the two option above, the things to note are: First; the characteristics of the cases currently handled by Bawaslu and Administrative High Court have similarities, namely dispute between the participant and the organizer of the object in the form of the decision of the organizer in the stages of determining the candidate pair. The difference is, Bawaslu decides disputes at the first level, which in this case is delegated to the District/City Panwaslu for dispute over election of regents/mayors and Provincial Bawaslu for dispute over governors election. Administrative High Court is an appeals court, only if the decision of Bawaslu in the dispute does note grant the objection of applicant.

Second; the authority to decide both institutions also have similarities. Bawaslu has an authority to order the organizers to revoke the disputed

${ }^{13}$ The Law Number 1 Year 2015 About Establishment of Government Regulation in lieu of The Law Number 1 Year 2014 Article 142-144.

${ }^{14}$ The Law Number 1 Year 2015 About Establishment of Government Regulation in lieu of The Law Number 1 Year 2014 Article 145-152.

${ }^{15}$ The Law Number 1 Year 2015 About Establishment of Government Regulation in lieu of The Law Number 1 Year 2014 Article 153-155.

${ }^{16}$ The Law Number 10 Year 2015 About The Second Amendment of The Law Number 1 Year 2015, Article 157. 


\section{Heru Widodo}

decision by the applicant. Administrative high court has the authority to revoke the decision by the plaintiff disputed. However, the validity of Bawaslu decision is final and binding, while the decision of administrative high court can still be filed an appeal to the Supreme Court. Thus, in the context of simplication and integration of institutional law enforcement, in principle, there is sufficient argument to combine the authority to resolve election disputes by not involving the court coverage under the Supreme Court, namely by establishing Bawaslu as the decider election dispute.

Related to the settlement of election disputes, the authority of a special "judicial board" as a institution who has authority to adjudicate also similar with the authority of institution which adjudicate the dispute stages, namely annul the decree of the KPU, if proven, and may also be followed by an instruction to KPU for holding a re-voting vote, re-voting or disqualifying candidate pairs.

In order to create integration of election law enforcement from the early stage until the end of the stage of determining the elected candidate pairs, the authority to settle the nominating dispute, election disputes and dispute on election result are given to the same institution namely Bawaslu, by separating from his position as part of the election organizer.

\section{Juridicial Argument in Setting the Choice of Institutional Design}

The juridicial argument in determining the choice of institutional design for Bawaslu to handle election disputes from the stage up to the end of the process of determining the elected candidate pairs, including the authority of the candidate settlement disputes, election disputes and election disputes can not be separated from Bawaslu institutional strengthening which commenced from the Constitutional Court's Decision Number 11/PUU-VII/2010 which has placed Bawaslu as an independent institution. By the Constitutional Court's decision mentioned, Bawaslu institutionaly no longer formed by the KPU is not a part of the KPU. Bawaslu's position is an independent institution with the same rank as the KPU, as an election organizer, which is national, permanent and independent.

In the law Number 15 Year 2011 on the Organizer of General Election of Bawaslu organization is strengthened by changing the Provincial Panwaslu to Provincial Bawaslu, which means to change the institution of provincial election supervisor institution who was "temporary" or adhoc, to be permanent. In addition, the 2012 Legislative Election Law also adds the authority of 
Bawaslu to resolve election disputes, namely disputes between election participants and disputes between election participants and election organizers. ${ }^{17}$

Institutional strengthening of Bawaslu continues, and lastly based on the Law number 10 Year 2016, the authority of Bawaslu covers the authority to decide on administrative offense, election disputes up to the handling money politics. Adminsitrative offense of the elections are offenses about procedures and mechanism relating to the administration of the elections in every stage of the administration of elections outside the crime of election and offense of the code of ethics of the election organizer. ${ }^{18}$

Based on the positive law of the day, Provincial Bawaslu and/or Regency/City Panwaslu made recommendations on the results of his study related to the violation of the Electoral Administration where the Provincial KPU and/or Regency/City KPU must follow up the recommendations of the Provoncial Bawaslu and/or Panwaslukada. ${ }^{19}$ Election disputes are: (a) disputes between election participants; and (b) the dispute between the election participant and the election organizer as a result of the issuance by the Provincial KPU and Regency/City KPU decisions. ${ }^{20}$ In terms of dispute over the regional head election, Bawaslu Election and Regency/City Panwaslu is authorized to resolve the dispute. ${ }^{21}$

In relation to handle money politics, the electional language of the election law defines the condition of money politics in which the candidate and/or team of the campaign are banned to promising and/or to providing money or other materials to influence the organizer of elections and/or the electors. ${ }^{22}$ In its explanation, the law provides a negative definition, which does not include "giving money or other materials" including the cost of feeding participants of campaign (consumptions), the cot of transporting campaign

17 The Law number 8 Year 2012 About General Election of Members of the People's Legislative Assembly, the Regional Representative Council and the Regional People's Legislative Assembly.

18 Article 138 The Law number 1 year 2015 as last modified by The Law number 10 year 2016.

${ }^{19}$ Article 139 Article 138 the Law number 1 Year 2015 as last modified by the Law number 10 Year 2016.

${ }^{20}$ Article 142 Article 138 the Law number 1 Year 2015 as last modified by the Law number 10 Year 2016.

${ }^{21}$ Article 143 Article 138 the Law number 1 Year 2015 as last modified by the Law number 10 Year 2016.

${ }^{22}$ Article 73 Paragraph (1) Article 138 the Law number 1 Year 2015 as last modified by the Law number 10 Year 2016. 


\section{Heru Widodo}

participants, the cost of procuring campaign materials in limited meetings and/or face-to-face and dialogues; other prizes based on the fairness and costliness of area determined by KPU Regulation. The Candidate who was proven to have commited money offenses based on the decision of the Provincial Bawaslu may be subject to administrative sanction of cancellation as a candidate pair by Provincial KPU or Regency/City KPU, as long as it occurs in TSM. ${ }^{23}$

The meaning of TSM is further described as follows. "Structured" is a fraud commited by the structural apparatus, either government or the organizer of the election collectively or together. "Systematic" is a well-planned, organized, even very neat offenses. "Massive" is the impact of a vast offense of its effect on election results not only in part.

From the description above, actually the authority of Bawaslu already very strong. The institution is adjudicating at the same time a disputes with a private dimension, namely dispute among election participants, dimension of state administration, namely settlement of administrative offense of election and dispute between participant and election organizer, and dimension of penalty, that sanction against money politicians, which that are considered to be highly reprehensible in society. Although Bawaslu does not have the authority to impose penal or imprisonment sanctions, the disqualification sessions of participants from election contestation are the toughest types of sanction for election participants since the objective of the election participants is to take up the contested public position.

Thus, Bawaslu and its subordinates have been transformed by individuals who have been established in every single election stage but not yet optimal. The lack of optimization due to administrative efforts carried out by Bawaslu related to administrative offense and election can still be challenged in the State Administrative Court as stipulated in Article 154 Paragraph (2) of the Regional Head Election Law.

Filling of a lawsuit over a state administrative dispute election to the State Administrative High Court shall be conducted after all administrative efforts in Provincial Bawaslu and/or District/City Panwaslu have been done. This situation can certainly extended the settlement process that lead to legal uncertainty.

${ }^{23}$ Article 135 A Article 138 the Law number 10 Year 2016. 
Next, it is about the authority of dispute settlement at the election result stage. At the election result stage, the Law the determination of election result vote shall be completed by a special judicial body where as long as the body has not yet been formed this authority submitted to the Constitutional Court to resolve. ${ }^{24}$

Based on the description below, it is appropriate if Bawaslu upgraded its institutional status into an institution that has administrative and judicial functions, or commonly called quasi judicial. Quasi Judicial institutions born out of the increasingly complex state problems led to many new institutions as supporting institutions established in order to assist the tasks of the three main institutions, namely the executive, legislative and judicial.

The formation of semi-judicial independent institutions is growing quite popular today, and is even widely imitated also among continental European countries which have a civil law tradition. ${ }^{25}$ One of the institutions which can be a reference is Commission of Business Competition Supervisor (KPPU). KPPU, theoretically is essence remains a semi-judicial or quasi-judicial institution. If it is associated to The "trias politica"Montesquiei theory, KPPU is more appropriate to be seen as a multi-function institution, not only executive, but also judicative. Moreover, as a quasi-judicial institution, the cases which handled by KPPU is not concerning for a criminal-law business only, but it's related to the administrative state too, even the criminal-law of each court is regulated to a various law, in case of practical necessary it must be integrated to one solution through KPPU.

The argumentation above can become a reason to improve Bawaslu institutional status as a board which resolve the dispute and complain happened in every stage of election. To make it as a credible board, Bawaslu decision is given a correction space, is a decision on the first stage in Local Bawaslu and can be submitted an appeal in National Bawaslu which has a final and binding decision. Thus, a selection process of a dispute which happened on the election would never involved The Supreme Court as a highest judicial authority. In case of the authority which given to Bawaslu, for the consequences are the regulation is issued from its position as a part of the organizer of election. As for institutional naming can be changed into Election Judicial Board.

\footnotetext{
${ }^{24}$ Article 156 jo. Article 157 Article 138 the Law Number 10 Year 2016

${ }^{25}$ Jimly Asshiddiqie, Mixed Function of KPPU as a Quasi-Justice Institution, page 4, this

$\begin{array}{llllll}\text { paper is downloaded on } 10 \text { January } & 2017 \text { from }\end{array}$ http://www.jimly.com/makalah/namafile/61/Makalah KPPU Koreksian.pdf
} 


\section{Heru Widodo}

\section{The Renewal of Authority Scope to Adjudicate Election Disputes}

The fundamental thing that can be suggested as an integral part of institutional reform related to the scope of the authority to adjudicate. The limitation of judicial authority of the judicial court is to examine and adjudicate cases of election disputes. In its current existence, as affirmed in the provisions of Article 157 section (1) of the constitution Number 8 in year 2015, ${ }^{26}$ the authority scope is only concerning the disputes on vote result that affect the result of election. ${ }^{27}$ The settlement of cases other than a controversy of vote result have become the authority of other institutions.

From the applicable legal enforcement mechanism, there is a limited coverage problem of legal events occurring within the period leading up to the day of election until the vote recapitulation. Those legal incidents may become money politics (paying voters/buying votes), physical and non-physical intimidation, bureaucratic politicization (mobilization of bureaucratic officials and civil servants), organizational alignments and omissions, sound infiltration or sound manipulation, which came from side of "times of occurrence", the legal events occur on a quiet day, heading to voting until the day of voting recapitulations.

Money Politics practice (paying voters/buying votes) is normatively has been regulated on article 73 of constitution Number 10 in year 2016 with the heaviest punishment is a disqualification to the candidates which proven to do TSM, has a range only to the acts that occurred and will be reported to the limit time up to 60 days before election day. The maximum limit time of reporting is regulated on Bawaslu Regulation Number 13 in year 2016, on article 27 section (2) which stipulates: "In seeking of substantive truths of reported TSM violations, the Report of Alleged TSM Violation is submitted to the Provoncial Bawaslu from the date of the enactment of the candidates to at least 60 days before election day."

In case of money politics on the 59th day before election day, even until the end of election stage, the law enforcement can be processed only through Gakkumdu Which no disqualification sanction may be applied to the prospective offender partner. The construction of law enforcement norms over money politics has created a legal loophole potentially disrupted by the election

\footnotetext{
${ }^{26}$ Article 157 verse (1) the Law number 8 year 2015 that said; "Cases of election outcome disputes are examined and tried by special judicial bodies."

27 According to Article 106 verse (2) the Law number 32 year 2004, that said: "Objection as referred to in verse (1) only relates to the results of vote counting which influence the election of a candidate pair."
} 
participants and their successful teams. In order to avoid the clarification of TSM violations, money politics is done after the reporting limit of 60 days before the voting.

In the same way with the election criminal process, there is a gap to enforce the law, according to the article 150 of the Law number 1 in year 2015, which states: The court's decision on a criminal act of election according to this law may affect the election vote of the contestant must be completed within 5 days before the Provincial KPU and/or Regency/Local KPU determines the result of election.

The regulation on the article was opened a legal gap in form of nonactionable cases of criminal election as long as it cannot be broken or resolved within 5 days before the determination of election result by KPU

Those legal gap can be solved by insert unreachable legal events towards legal enforcement on criminal system and election dispute stage. To conclude, the range of dispute of election result covering on a legal occurrence in the quiet period, election night as the last time to influence an election, beginning from the election day to recapitulation day, potential becomes a controversy, either an administrative violence or criminal. Yet, an authority of the institution dispute of election result has been limited only to assess the happen violence whether it influences a configuration vote and wins an election. Based on the argumentation, then the norms of the requirement of filing a complaint of election result by the range $0,5-2 \%$ of total resident has become irrelevant to be implemented.

\section{Conclusion}

The three bases of an ideal renewal of institutional design to adjudicate a dispute of election result. First, a constitutional design of the establishment special judicial board as a part of judicial environment under Supreme Court is written on article 24 section (2) of Indonesia constitution 1945, while in the form of a new institution or to replace an exist board is referred to the article 24 section (3) of constitution 1945. A choice of institutional design is suggested not by forming a new board, but by attaching an authority to an exist judicial board. A current authorized board of judging an election dispute are three: Bawaslu, PT TUN, and Constitutional Court (transitionally)

Second, the juridical argumentation of an establishment Bawaslu as a choice: is beginning by strengthening the institutional of Bawaslu since decree 


\section{Heru Widodo}

of Constitution Court number 11/PUU-VIII/2010, and changing of local election supervisor to a permanent board. In the legislative election 2014, Bawaslu has an authority to settle the dispute up among candidates or between a candidate and the committee. In the simultaneously election, Bawaslu has an authority to judge an administrative violence, election dispute, and money politics handling by TSM. Bawaslu has become a judicial board from a private problem into a state administrative problem by increasing an institutional status and has become administrative and judicial function.

Third, An authority range to adjudicate a dispute of election result has been suggested covering a controversy of result count and unreachable legal incident by enforcing a law in criminal system of election and dispute of election stage which cannot be separated. The authority is limited only to assess the happen violence whether it influences a configuration vote and wins an election.

\section{References:}

Asshiddiqie, Jimly, Makalah "Fungsi Campuran KPPU Sebagai Lembaga Quasi-Peradilan" tanpa tahun.

Asshiddiqie, Jimmly, dkk., Putusan Monumental, Menjawab Problematika Kenegaraan, Malang: Setara Press dan Forum Kajian Yurisprudensi, 2016.

Barak, Aharon, The Judge in a Democracy, New Jersey: Princeton University Press, 2008.

Harijanti, Susi Dwi dan Ali Abdurrahman, "Model Penyelesaian Sengketa Pemilu Oleh Mahkamah Konstitusi: Studi Perbandingan Antara Indonesia Dan Jerman", Laporan Penelitian Fakultas Hukum Universitas Padjadjaran, Bandung 2011.

Henriquez, Jesús Orozco, The Mexican System of Electoral Conflict Resolution in Comparative Perspective, Taiwan Journal of Democracy, Volume 2, No.1.

Kelsen, Hans, Pengantar Teori Hukum, Bandung: Nusa Media, 2012.

Friedman, Lawrence M. Sistem Hukum Perspektif Ilmu Sosial, (A Legal System a Social Science Perspective), diterjemahkan oleh M. Khozim, Bandung: Nusa Media, 2009.

Salim HS dan Erlies Septiana Nurbani, Penerapan Teori Hukum pada Penelitian Tesis dan Disertasi, Jakarta: Raja Grafindo, 2013. 
Yunus, Nur Rohim. Restorasi Budaya Hukum Masyarakat Indonesia, Bogor: Jurisprudence Press, 2012.

Undang-Undang Nomor 8 Tahun 2012 tentang Pemilihan Umum Anggota Dewan Perwakilan Rakyat, Dewan Perwakilan Daerah, dan Dewan Perwakilan Rakyat Daerah.

Undang-Undang Nomor 1 Tahun 2015 Tentang Penetapan Peraturan Pemerintah Pengganti Undang-Undang Nomor 1 Tahun 2014 Tentang Pemilihan Gubernur, Bupati, Dan Walikota Menjadi Undang-Undang

Undang-Undang Nomor 10 Tahun 2015 tentang Perubahan Kedua Atas Undang-Undang Nomor 1 Tahun 2015 Tentang Penetapan Peraturan Pemerintah Pengganti Undang-Undang Nomor 1 Tahun 2014 Tentang Pemilihan Gubernur, Bupati, Dan Walikota Menjadi Undang-Undang

Undang-Undang Nomor 8 Tahun 2015 tentang Perubahan Atas UndangUndang Nomor 1 Tahun 2015 Tentang Penetapan Peraturan Pemerintah Pengganti Undang-Undang Nomor 1 Tahun 2014 Tentang Pemilihan Gubernur, Bupati, Dan Walikota Menjadi Undang-Undang. 
Heru Widodo 


\section{JURNAL}

\section{CITA HUXUM INDONESIAN LAW JOURNAL}

\section{TECHNICAL GUIDANCE FOR AUTHORS OF CITA HUKUM JOURNAL}

1. Article must be original, not plagiarism, unpublished, and not under review for possible publication in other journals.

2. Article should be concept, research-based, and toughts;

3. Article should be written in Bahasa Indonesia or English

4. Article must contain of Law Science

5. Writing Guidance as follows:

a. Title is written by Capital maximum 12 words in the center

b. Name of authors are written completely, no degree, institutional affiliation, address, and email.

c. Abstract is written in Bahasa Indonesia or English maximum 120 words.

d. Systematycs of article:

1) Title

2) Name of authors (no title), name of affiliation, email

3) Abstract

4) Keywords, between 2-5 words

5) Introduction

6) Sub title (if need it)

7) Closing

8) Bibliography (The bibliography list contains all references in text originating from sources that are relevant and at least up to date (last 10 years).

e. Paper Sizes are $17,5 \times 24 \mathrm{~cm}$, up $2,5 \mathrm{~cm}$, down, $2,5 \mathrm{~cm}$, right $2,5 \mathrm{~cm}$, and left $2,5 \mathrm{~cm}$

f. Length of article is between $18-20$ pages with 1.0 line spacing , Palatyno Fond Style with 10 size.

g. Rule of citation. Direct citation if word is more than 4 lines separated from the text with 1.0 spacing with 9 font. However if citation less than 4 lines, it should be integrated in the text with double apostrof both in the first and in the end. Every citation is given number. Citation system is footnote not body note or endnote and use turabia system. Every article, book, and other source should be citated on the reference.

h. Citation for Quran and Hadist. For verse citation contains name of surah, number of surah and number of verse example: (Qs. Al Mumin [40]: 43). For Hadis citation, mention name of Perawi/Author, example (H. R al-Bukhari and Muslim) and printed hadist version. Hadist must be from standar hadist books (Kutub at-Tisah).

i. Footnote is written by Palatino Linotype style, size 8 , for any sources as follows:

1) Book: Author's name (without title), title of book (place publised: publisher, year of published), Version, Volume, Batch, Page. Example: Soerjono Soekanto, Pokok-Pokok Sosiologi Hukum, (Jakarta: Rajawali Press, 1986), p. 10. 
2) Translated Book. Example: Roscoe Pound, Pengantar Filsafat Hukum: Book III, translated by Moh. Radjab, (Jakarta: Bharata, 1963), p.15.

3) Journal, example: Nur Rohim Yunus, "Kontroversi Pembentukan Perppu No. 1 Tahun 2013 tentang Mahkamah Konstitusi Dalam Ranah Kegentingan Yang Memaksa", Jurnal Cita Hukum, Volume 1 Number 1 (2014), p.157.

4) Article as a part of book (antology). Contoh: Hikmahanto Juwana, "Penegakan Hukum dalam Kajian Law and Development: Problem dan Fundamen bagi Solusi Indonesia", in Muhammad Tahir Azhary, Beberapa Aspek Hukum Tata Negara, Hukum Pidana, dan Hukum Islam, (Jakarta: Kencana Prenada Media Group, 2012), p.127.

5) Article from internet, example: Ahmad Tholabie Kharlie, "Problem Yuridis RUU Syariah" in http://ahmadtholabi.com/2008/03/03problem-yuridis-ruu-syariah, downloaded on March 20, 2012.

6) Article from magazine, example: Susilaningtias, "Potret Hukum Adat pada Masa Kolonial", in Forum Keadilan, No. 17, August 20, 2017.

7) Article in Seminar, example: Jimly Asshidiqqie, "Kedudukan Mahkamah Konstitusi dalam Struktur Ketatanegaraan Indonesia", paper presented on public lecture at faculty of law Universty Sebelas Maret, Surakarta on March 2, 2014.

j. Bibliography. Bibliography is written alphabeticaly, last author's name is in the first of name, example:

1) Book: Soekanto, Soerjono, Pokok-Pokok Sosiologi Hukum, Jakarta: Rajawali Press, 1986.

2) Translated Book. Example: Pound, Roscoe, Pengantar Filsafat Hukum: Book III, translated by Moh. Radjab, Jakarta: Bharata, 1963.

3) Journal, example: Rohim, Nur, "Kontroversi Pembentukan Perppu No. 1 Tahun 2013 tentang mahkamah konstitusi dalam ranah kegentingan yang memaksa", Jurnal Cita Hukum, Volume 1 Number 1 (2014).

4) Article as a part of book (antology). example: Juwana, Hikmahanto, "Penegakan Hukum dalam Kajian Law and Development: Problem dan Fundamen bagi Solusi Indonesia", in Muhammad Tahir Azhary, Beberapa Aspek Hukum Tata Negara, Hukum Pidana, dan Hukum Islam, Jakarta: Kencana Prenada Media Group, 2012.

5) Article from internet, example: Kharlie, Ahmad Tholabie, "Problem Yuridis RUU Syariah" in http://ahmadtholabi.com/2008/03/03problem-yuridis-ruu-syariah, downloaded on March 20, 2012.

6) Article from magazine, example: Susilaningtias, "Potret Hukum Adat pada Masa Kolonial", in Forum Keadilan, No. 17, August 20, 2016.

7) Article in Seminar, example: Asshidiqqie, Jimly, "Kedudukan Mahkamah Konstitusi dalam Struktur Ketatanegaraan Indonesia", paper presented on public lecture at faculty of law Universty Sebelas Maret, Surakarta on March 2, 2014.

k. Closing, article is closed by conclusion;

I. Short biography: author's biography contains full name, title, institution, education and other academic experts.

6. Every article that doesnt fufill all requirements to this guidance will give it back to the author for revision.

7. Article must be submitted to editors at least 3 months before publishing (June and December) with uploading via OJS to http://journal.uinjkt.ac.id/index.php/citahukum or e-mail to jurnal.citahukum@uinjkt.ac.id.] 


\section{PEDOMAN TEKNIS PENULISAN BERKALA ILMIAH JURNAL CITA HUKUM}

1. Artikel adalah benar-benar karya asli penulis, tidak mengandung unsur plagiasi, dan belum pernah dipublikasikan dan/atau sedang dalam proses publikasi pada media lain yang dinyatakan dengan surat pernyataan yang ditandatangani di atas meterai Rp 6000;

2. Naskah dapat berupa konseptual, resume hasil penelitian, atau pemikiran tokoh;

3. Naskah dapat berbahasa Indonesia atau Inggris;

4. Naskah harus memuat informasi keilmuan dalam ranah ilmu hukum Positif;

5. Aturan penulisan adalah sebagai berikut:

a. Judul. Ditulis dengan huruf kapital, maksimum 12 kata diposisikan di tengah (centered);

b. Nama penulis. Ditulis utuh, tanpa gelar, disertai afiliasi kelembagaan dengan alamat lengkap, dan alamat e-mail;

c. Abstrak. Ditulis dalam bahasa Indonesia dan bahasa Inggris masing-masing hanya 120 kata saja;

d. Sistematika penulisan naskah adalah sebagai berikut:

1) Judul;

2) Nama penulis (tanpa gelar akademik), nama dan alamat afiliasi penulis, dan e-mail;

3) Abstrak;

4) Kata-kata kunci, antara 2-5 konsep yang mencerminkan substansi artikel;

5) Pendahuluan;

6) Sub judul (sesuai dengan keperluan pembahasan);

7) Penutup; dan

8) Pustaka Acuan (hanya memuat sumber-sumber yang dirujuk dan sedapat mungkin terbitan 10 tahun terakhir).

e. Ukuran kertas yang digunakan ukuran $17,5 \times 24 \mathrm{~cm}$, margin: atas $2,5 \mathrm{~cm}$, bawah $2.5 \mathrm{~cm}$, kiri 2,5 $\mathrm{cm}$, dan kanan 2,5 cm;

f. Panjang Naskah antara 18 s.d. 20 halaman, spasi 1, huruf Palatino Linotype, ukuran 10;

g. Pengutipan kalimat. Kutipan kalimat ditulis secara langsung apabila lebih dari empat baris dipisahkan dari teks dengan jarak satu spasi dengan ukuran huruf 9 point. Sedangkan kutipan kurang dari empat baris diintegrasikan dalam teks, dengan tanda apostrof ganda di awal dan di akhir kutipan. Setiap kutipan diberi nomor. Sistem pengutipan adalah footnote (bukan bodynote atau endnote). Penulisan footnote menggunakan sistem turabian. Setiap artikel, buku, dan sumber lainnya yang dikutip harus tercantum dalam pustaka acuan;

$h$. Pengutipan Ayat Alquran dan Hadis. Ayat yang dikutip menyertakan keterangan ayat dalam kurung, dengan menyebut nama surah, nomor surah, dan nomor ayat, seperti (Q.S. al-Mu'min [40]: 43). Pengutipan Hadis menyebutkan nama perawi (H.r. al-Bukhārī dan Muslim) ditambah referensi versi cetak kitab Hadis yang dikutip. Hadis harus dikutip dari kitab-kitab Hadis standar (Kutub al-Tis'ah);

i. Cara pembuatan footnote. Footnote ditulis dengan font Palatino Linotype, Size 8, untuk pelbagai sumber, antara lain:

1) Buku: nama utuh penulis (tanpa gelar), judul buku (tempat terbit: penerbit, tahun terbit), cetakan, volume, juz, halaman. Contoh: Soerjono Soekanto, Pokok-pokok Sosiologi Hukum, (Jakarta: Rajawali Pers, 1986), h. 10.

2) Buku terjemahan, contoh: Roscoe Pound, Pengantar Filsafat Hukum: Buku III, diterjemahakan oleh Moh. Radjab, (Jakarta: Bharata, 1963), h. 15;

1) Jurnal, contoh: Nur Rohim Yunus, "Kontroversi Pembentukan Perppu No. 1 Tahun 2013 tentang mahkamah konstitusi dalam ranah kegentingan yang memaksa", dalam Jurnal Cita Hukum, Vol. I, No. 1, Juni 2014, h. 157. 
2) Artikel sebagai bagian dari buku (antologi), contoh: Hikmahanto Juwana, "Penegakan Hukum dalam Kajian Law and Development: Problem dan Fundamen bagi Solusi Indonesia", dalam Muhammad Tahir Azhary, Beberapa Aspek Hukum Tata Negara, Hukum Pidana, dan Hukum Islam, (Jakarta: Kencana Prenada Media Gorup, 2012), h.127.

3) Artikel dari internet, contoh: Ahmad Tholabi Kharlie, "Problem Yuridis RUU Syariah" dalam http://ahmadtholabi.com/2008/03/03/problem-yuridis-ruu-syariah, diunduh pada 20 Maret 2012.

4) Artikel dari majalah, contoh: Susilaningtias, "Potret Hukum Adat pada Masa Kolonial", dalam Forum Keadilan, No. 17, 20 Agustus 2006.

5) Makalah dalam seminar, contoh: Jimly Asshiddiqie, "Kedudukan Mahkamah Konstitusi dalam Struktur Ketatanegaraan Indonesia", Makalah disampaikan dalam Kuliah Umum Fakultas Hukum Universitas Sebelas Maret, Surakarta, pada 2 Maret 2004.

j. Pustaka Acuan: daftar pustaka acuan ditulis sesuai urutan abjad, nama akhir penulis diletakkan di depan. Contoh:

1) Buku, contoh: Soekanto, Soerjono, Pokok-pokok Sosiologi Hukum, Jakarta: Rajawali Pers, 1986.

2) Buku terjemahan, contoh: Pound, Roscoe, Pengantar Filsafat Hukum: Buku III, diterjemahakan oleh Moh. Radjab, Jakarta: Bharata, 1963.

3) Jurnal, contoh: Rohim, Nur, "Kontroversi Pembentukan Perppu No. 1 Tahun 2013 tentang mahkamah konstitusi dalam ranah kegentingan yang memaksa", dalam Jurnal Cita Hukum, Vol. I, No. 1, Juni 2014.

4) Artikel sebagai bagian dari buku, contoh: Juwana, Hikmahanto, "Penegakan Hukum dalam Kajian Law and Development: Problem dan Fundamen bagi Solusi Indonesia", dalam Muhammad Tahir Azhary, Beberapa Aspek Hukum Tata Negara, Hukum Pidana, dan Hukum Islam, Jakarta: Kencana Prenada Media Gorup, 2012.

5) Artikel yang dikutip dari internet, contoh: Kharlie, Ahmad Tholabi, "Problem Yuridis RUU Syariah" dalam http://ahmadtholabi.com/2008/03/03/problem-yuridis-ruu-syariah, diunduh pada 20 Maret 2012.

6) Majalah, contoh: Susilaningtias, "Potret Hukum Adat pada Masa Kolonial", dalam Forum Keadilan, No. 17, 20 Agustus 2006.

7) Makalah dalam seminar, contoh: Asshiddiqie, Jimly, "Kedudukan Mahkamah Konstitusi dalam Struktur Ketatanegaraan Indonesia", Makalah disampaikan dalam Kuliah Umum Fakultas Hukum Universitas Sebelas Maret, Surakarta, pada 2 Maret 2004.

k. Penutup: artikel ditutup dengan kesimpulan;

I. Biografi singkat: biografi penulis mengandung unsur nama (lengkap dengan gelar akademik), tempat tugas, riwayat pendidikan formal (S1, S2, S3), dan bidang keahlian akademik;

6. Setiap naskah yang tidak mengindahkan pedoman penulisan ini akan dikembalikan kepada penulisnya untuk diperbaiki.

7. Naskah sudah diserahkan kepada penyunting, selambat-lambatnya tiga bulan sebelum waktu penerbitan (Juni dan Desember) dengan mengupload langsung via OJS ke alamat: http://journal.uinjkt.ac.id/index.php/citahukum atau via e-mail ke: jurnal.citahukum@uinjkt.ac.id.[] 
in Collaboration with :

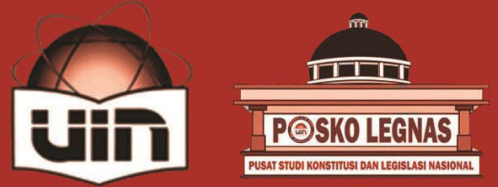

Indexed by :
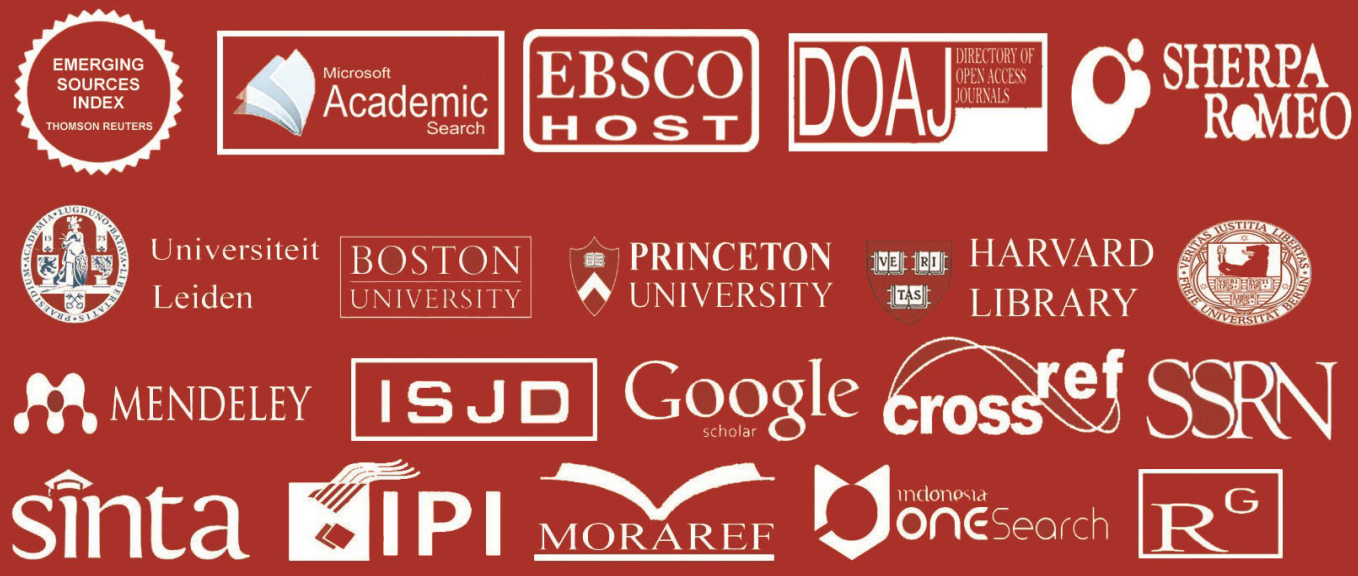

JURNAL CITA HUKUM is a peer-reviewed journal on Indonesian Law Studies published biannual (June \& December) by Faculty of Sharia and Law Universitas Islam Negeri Syarif Hidayatullah Jakarta in cooperation with Center for the Study of Constitution and National Legislation (POSKO-LEGNAS). JURNAL CITA HUKUM aims primarily to facilitate scholarly and professional discussions over current developments on legal issues in Indonesia as well as to publish innovative legal researches concerning Indonesian laws.
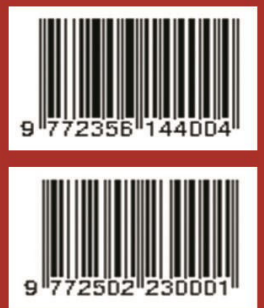